DOI: 10.5604/01.3001.0012.0716

\title{
PROPOSAL FOR MANAGING ELECTRIC ENERGY QUALITY IN THE LV GRID USING ON-LOAD TAP CHANGER WITH A STATIC SYNCHRONOUS COMPENSATOR
}

\author{
Bartlomiej Mroczek, Karol Fatyga \\ Lublin University of Technology, Faculty of Electrical Engineering and Computer Science, Department of Electrical Drives and Machines
}

Abstract. The paper proposes the use of auxiliary equipment in the low voltage network: an on-load tap changer and a static synchronous compensator (STATCOM) to improve the quality of energy supply to end users. As part of the research, a section of medium and low voltage power grid was modelled using Matlab \& Simulink software, which was tested in three scenarios. The first scenario presents the operation of the power grid with the on-load tap changer installed in the transformer block. The second scenario uses the STATCOM for local reactive power compensation. Additionally, the third scenario is the combined work of the on-load tap-changer along with the STATCOM. According to the authors, the method discussed does not bring the expected results in the area of voltage quality improvement, indicating that further research is required, including tests with energy storage.

Keywords: On-Load Tap Changer (OLTC), Static Synchronous Compensator (STATCOM), energy quality

\section{PROPOZYCJA ZARZĄDZANIA JAKOŚCIĄ NAPIĘCIA Z WYKORZYSTANIEM PODOBCIĄŻENIOWEGO PRZELĄCZNIKA ZACZEPÓW TRANSFORMATORA I KOMPENSATORA STATCOM}

\begin{abstract}
Streszczenie. W artykule zaproponowano zastosowanie pomocniczych urządzeń w sieci niskiego napięcia: podobciążeniowego przełacznika zaczepów oraz kompensatora mocy biernej (STATCOM) w celu poprawy jakości energii dla odbiorców końcowych. Zamodelowano fragment sieci elektroenergetycznej średniego i niskiego napięcia za pomoca oprogramowania Matlab \& Simulink, który został poddany badaniu w ramach trzech scenariuszy. Pierwszy scenariusz prezentuje pracę sieci elektroenergetycznej z podobciązeniowym przełacznikiem zaczepów zainstalowanym $w$ kadzi transformatora. Drugi scenariusz wykorzystuje STATCOM do lokalnej kompensacji mocy biernej. Natomiast trzeci scenariusz jest to jednoczesna praca podobciązeniowego przełącznika zaczepów wraz ze STATCOM. Zaprezentowany sposób wedlug autorów nie przynióst oczekiwanych rezultatów w zakresie poprawy jakości napięcia $i$ wskazuje na dalsza potrzebę badawczą z wykorzystaniem magazynów energii.
\end{abstract}

Słowa kluczowe: podobciążeniowy przełącznik zaczepów transformatora, STATCOM, jakość energii

\section{Introduction}

Due to disturbances caused by dissymmetric operation, short circuits, or power shortages, the quality of energy supplied from utility grid can be disturbed. The utility grid operator simply cannot guarantee the quality of energy supply. For example, the utility grid cannot provide enough energy in the case of a voltage drop. This may cause disturbances in the operation of the device on the end user side. In severe cases, it can cause unpredicted shutdowns and stops - actions that are not welcome especially in industry. Additionally, when a local electrical installation is equipped with an undervoltage safety system, it creates a local shutdown for all the devices supplied from that grid.

A phenomenon described as a rapid voltage reduction dropping below the set threshold value in no shorter time than 10 $\mathrm{ms}$ and ending by voltage returning back to normal is called a voltage sag [9]. Two types of incidents can cause a voltage sag to occur. The first of them are short circuits in the utility grid, when there is a rapid impedance drop, and as a consequence the grid current rises up to the short circuit current value. The other type is events connected with starting industrial processes, which require large starting power - and large inrush currents. During these processes the grid load changes dynamically along with the impedance of the receivers [4].

In practice, counteracting voltage sags or, to be more precise, handling their consequences is based on using additional devices, which aim to keep the voltage in the range of $\pm 10 \%$ of the rated grid voltage. The choice of the devices, as well as their location, have a direct impact on the final effect of voltage regulation and the improvement of energy quality. Moreover, the choice of the device type, according to its ability to store energy, can influence the reduction of voltage sag consequences, and even protect from energy shortages [16].

\section{Influence of the load profile change on energy quality}

In Europe, grid management and development is beginning to drift towards so called "smart grid" solutions, and control of energy quality in real time [2]. Energy supply quality at user connection point is a service quality indicator, and according to $\S 38$ act 3. p 2 of regulation [5], every week at least 95\% of 10-minute average RMS voltage values has to fall between $\pm 10 \%$ of the rated grid voltage for connection groups III-V.

The occurrence of short voltage sags that are allowed by the cited regulation is inconvenient for end users. Because of that, it is advisable to use devices that reduce the impact of short voltage sags on end users.

Power demand during the day is not constant. It is influenced by the time of day, season of the year and current end-user demands. Because of that, temporary, or constant energy demand that is higher than the one for which the grid was designed causes a drop in the quality of energy supply that exceeds the limit permissible in the regulation [14].

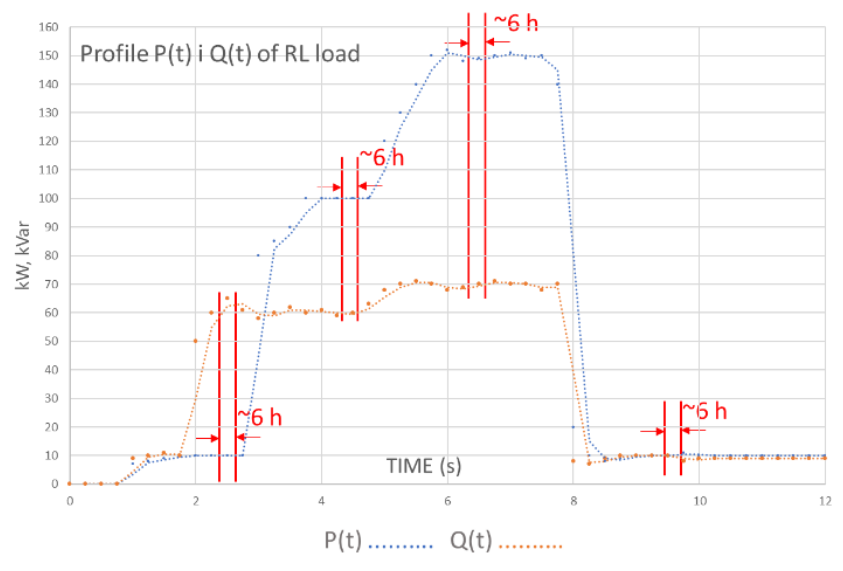

Fig. 1. Active power profile $P$ (navy blue) and reactive $Q$ (orange) for the tested part of the distribution network (LV line, load)

In order to create temporary voltage values in the chosen utility grid points, the end-user group profile was defined for both active power $P$ and reactive power $Q$, which is shown in Figure 1 .

The existing connection system of the distribution network for both the medium voltage (MV) and low voltage (LV) can be modelled as a simplified circuit, shown in Figure 2. 


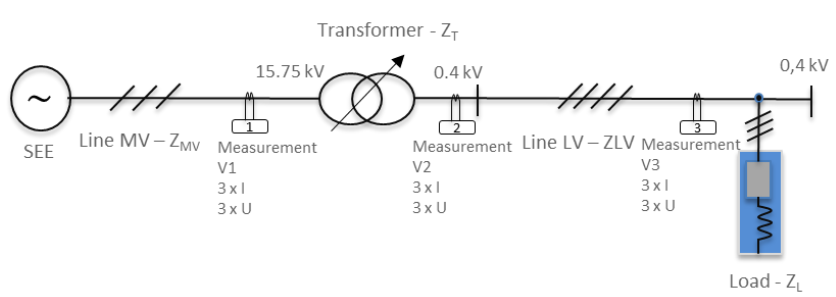

Fig. 2. Schematic diagram of part of the distribution network, where: $S E E$ - power system, $Z_{M V}-M V$ line impedance, $Z_{L V}-L V$ line impedance, $Z_{T}$-transformer impedance, $Z_{L}$ - load impedance, $V I$ - voltage side of the primary side of the transformer, V2 - voltage secondary side measurement of the transformer $V 3$ - voltage measurement at the receiving energy

The impedance of the exemplary distribution network fragment was derived separately for an MV line, an MV/LV transformer, an LV line and a load with RL characteristics.

Table 1. Nominal data of the MV and LV fragment of the power grid

\begin{tabular}{|c|c|}
\hline Power network parameters & Value \\
\hline Frequency & $50 \mathrm{~Hz}$ \\
\hline Voltage phase to phase MV & $15 \mathrm{kV}$ \\
\hline Type of wire MV & AFL $3 \times 70 \mathrm{~mm}^{2}$ \\
\hline Length of the MV line & $10 \mathrm{~km}$ \\
\hline St - power of transformer & $100 \mathrm{kVA}$ \\
\hline$P_{\mathrm{Fe}}-$ non-load loss & $199 \mathrm{~W}$ \\
\hline$P_{\mathrm{cu}}-$ load loss & $1920 \mathrm{~W}$ \\
\hline$U_{\mathrm{z}}-$ short-circuit voltage & $4 \%$ \\
\hline Transformer ratio & $\mathrm{GN}: 15,75 \mathrm{DN}: 0,4 \pm 10 \%$ \\
\hline Connection system & $\mathrm{Dyn} 5$ \\
\hline Type of the LV wire & AFL $4 \times 35 \mathrm{~mm}^{2}$ \\
\hline L of the LV line & $1,5 \mathrm{~km}$ \\
\hline Active and Reactive Power RL Load & P $=150 \mathrm{~kW}, \mathrm{Q}=60 \mathrm{kVar}$ \\
\hline
\end{tabular}

To simplify the control algorithm for both active and reactive power, a transformation from stationary into rotating orthogonal reference frame $d q$ occurs. The definition of voltage vector $V_{s}$ in a synchronously rotating reference frame is:

$$
\underline{V}_{S}=V_{d}+j V_{q}=\left(V_{\alpha}+j V_{\beta}\right) e^{-j \omega t}
$$

where: $V_{\mathrm{d}}$ - active component in the $d q$ frame, $V_{\mathrm{q}}$ - reactive component in the $d q$ frame, $V_{\alpha}$ - voltage component in the $\alpha \beta$ frame, $V_{\beta}$-voltage component in $\alpha \beta, \omega$ - grid angular frequency.

Using the Clarke transform, three phase signals $\left(U_{a}, U_{b}, U_{c}\right)$ are transformed into a 2-phase orthogonal stationary frame $\alpha \beta$ :

$$
V_{\alpha}+j V_{\beta}=\frac{2}{3}\left(U_{a}+U_{b} e^{\frac{j 2 \pi}{3}}+U_{c} e^{\frac{-j 2 \pi}{3}}\right)
$$

Next, using the Park transform, 2-phase signals are transformed from stationary frame $\alpha \beta$ into rotating reference frame $d q$. The $V \mathrm{~d}, V \mathrm{q}$ signals can be defined as:

$\left[\begin{array}{l}V_{d} \\ V_{q}\end{array}\right]=\frac{2}{3}\left[\begin{array}{lll}\sin (\omega t) & \sin \left(\omega t-\frac{2 \pi}{3}\right) & \sin \left(\omega t+\frac{2 \pi}{3}\right) \\ \cos (\omega t) & \cos \left(\omega t-\frac{2 \pi}{3}\right) & \cos \left(\omega t+\frac{2 \pi}{3}\right)\end{array}\right] \times\left[\begin{array}{c}U_{a} \\ U_{b} \\ U_{c}\end{array}\right]$

This transform allows changing from a stationary three-phase reference frame into a rotating orthogonal reference frame on the $d q$ plane [17].

Based on grid parameters presented in Table 1, voltage waveforms in points V1 (Fig. 3), V2 (Fig. 4), V3 (Fig. 5) were derived.

They represent relational voltage values in synchronously rotating reference frame $\mathrm{dq}$, related to the rated voltage of the primary and secondary side of the transformer.

First, exemplary voltage waveforms $V \mathrm{~d}$ and $V \mathrm{q}$ for the primary side of the transformer $-V 1$, with simulated load profile change is presented (Fig. 3).

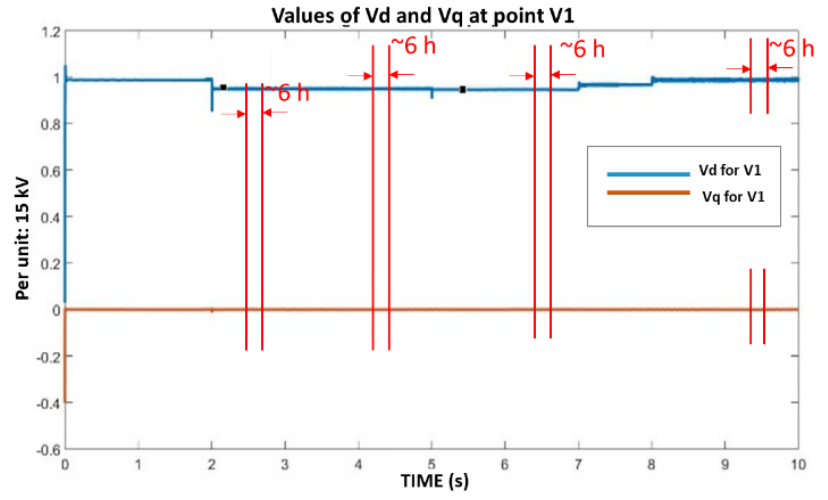

Fig. 3. Values of $V_{d}$ and $V_{q}$ at point $V 1$

The voltage drop that can be observed between $t=2 \mathrm{~s}$ to $\mathrm{t}=8$ $\mathrm{s}$ is caused by the load profile change according to assumptions from Figure 1. It is still in the range of $\pm 10 \%$ of the grid's rated voltage. The null value of component $V_{\mathrm{q}}=0$ shows full synchronization with the grid on the medium voltage side of the transformer.

For exactly the same disturbance, the voltage in the V2 measurement point behaves similarly. The $V_{\mathrm{d}}$ and $V_{\mathrm{q}}$ component values are presented in Figure 4.

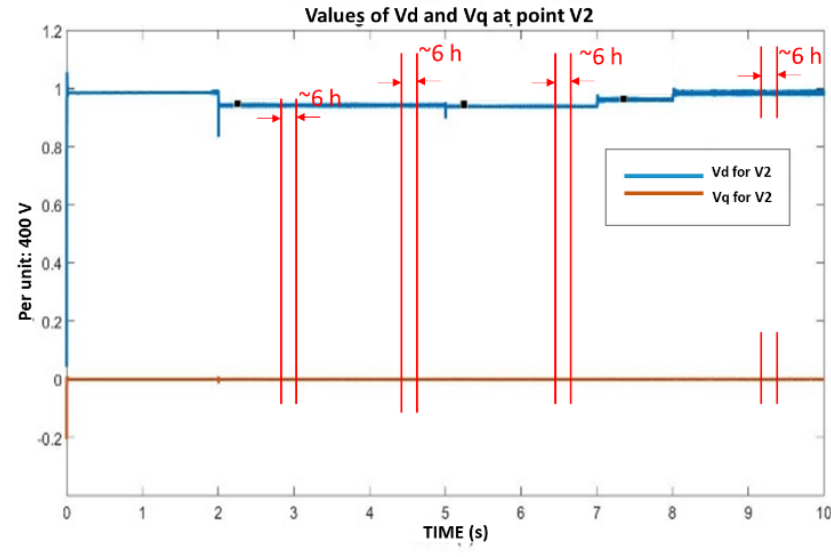

Fig. 4. Values of Vd and Vq at point V2

Just as in the case of measurement point $V 1$, a change of load profile in point $V 2$ did not cause voltage sags exceeding the threshold of $\pm 10 \%$ of the rated grid voltage.

The situation changes when we consider the influence of the load profile change in measurement point $V 3$ (Fig. 5).

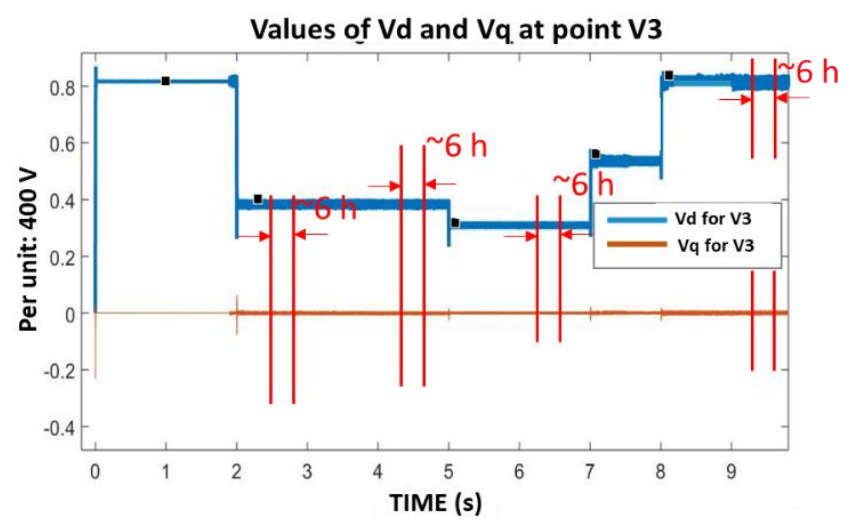

Fig. 5. Values of $V_{d}$ and $V_{q}$ at point $V 3$ 
In $V 3$ measurement point, being the closest to the distribution grid load, a large voltage sag can be observed, which exceeds the allowable $\pm 10 \%$ of the rated grid voltage. This is connected to end users exceeding their load profiles $P$ and $Q$.

Taking these results into account, consideration of the quality of energy supply in MV and LV distribution grids, as well as the strategy of its management, has to be connected with deep analysis of several grid measurement points. It has to be pointed out that a load profile change is followed by voltage drops in impedance elements, and the farther the load is from the supply, the larger the voltage sag. From this, a scientific problem arises, consisting in the need to judge technological decisions and point in the direction of strategy development for energy quality in low voltage grids [6].

\section{Energy quality improvement solution analysis}

The proposed solution for the scientific problem defined in the previous section is equipping the utility grid presented in Figure 2 with additional devices that greatly improve energy quality in the low voltage grid. The first device is the On-Load Tap Changer (OLTC) [3], the other is the Static Synchronous Compensator (STATCOM) [12]. To control the operation of these devices a central control unit AVC (Automatic Voltage Control) is needed, which acts as an automated system for voltage management in a low voltage grid LV [5]. The idea of implementing additional equipment into the grid is presented in Figure 6.

Using an On-Load Tap Changer aims to apply step compensation of voltage sags in MV line $-V 1$, and on transformer impedance $-V 2$. The task assigned for the STATCOM is reactive current compensation in a grid fragment that is monitored at the $V 3$ measurement point.

For the operating grid, a suitable reaction, and as a consequence voltage regulation in each of the points $V 1, V 2, V 3$, is of paramount importance. Using both the OLTC and STATCOM in same grid fragment requires developing rules and conditions for their independent or cooperative operation. In a fully developed solution, these should be implemented into the main controller AVC.

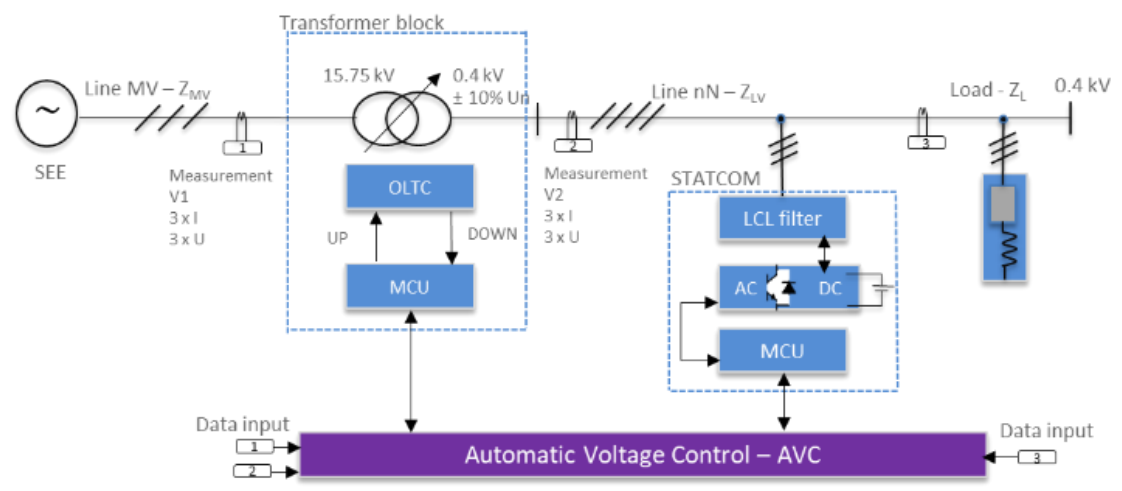

Fig. 6. Schematic diagram of part of the distribution network with OLTC and STATCOM, where: OLTC-on-load tap changer, MCU - microcontroller, AC/DC-power inverter

\subsection{Operating conditions of the On-Load Tap Changer}

A commonly used device in the distribution grid is a transformer equipped with tap changers that are placed in the transformer tank [8]. These allow to change voltage on the secondary side of the transformer. Due to lower current values, a tap changer is installed on the primary side of the transformer. The tap-changer position switch changes the number of turns on the primary side of the transformer, which - combined with the constant number of turns on the secondary side - causes change in the transformer ratio. This enables control of the secondary side voltage by changing the primary side voltage in the range of $\pm U_{N} \%$ of the rated grid voltage. Currently, two types of tap changers are used: off-load tap changers, used only in no voltage states of the transformer - these are commonly found in distribution stations [8], or on-load tap changers, which allow turn change without any power breaks [7]. The control mechanism, which is responsible for changing transformer taps is implemented into a MCU microcontroller, and operates in real time, based on voltage value on the low-voltage side. The microcontroller acts on the transformer by using a tap selector with transition resistors. To ensure proper voltage regulation on the secondary side of the transformer, four conditions for OLTC switching were defined as follows:

Condition 1: Tap-changer position switch:

$$
n=n_{0}+\Delta n f\left(z_{n}\right)
$$

where: $z_{\mathrm{n}}-$ OLTC work interval range between states, $n$-state of the OLTC, $n_{0}$ - nominal position of the OLTC.

The above condition has additional mechanical restrictions of the number of $n$ positions, bound to the transformer construction and regulation needs. The description of the OLTC's condition 1 is:

$$
\operatorname{OLTC.1}\left(n_{n}\right)=\left\{\begin{array}{c}
T A P 1 \text { UP, if: }: \frac{U_{N}}{n_{n}}<U_{\text {current value }} \\
T A P n_{0}, \text { if: } U_{N}=U_{\text {current value }} \\
T A P 1 D O W N, \text { if }: \frac{U_{N}}{n_{n}}>U_{\text {current value }}
\end{array}\right\}
$$

where: $U_{\mathrm{N}}$ - the nominal value for a given voltage level.

Condition 1 is the base algorithm for the state space machine allowing the voltage control mechanism to operate properly over time.

Condition 2: The limit of position changes as a method to prolong the tap changer's lifecycle:

$$
\text { OLTC. } 2=\sum_{k} k_{\text {OLTC2 }} \leq k_{p}
$$

where: $k_{\mathrm{p}}(\mathrm{t})-$ the number of switching cycles $(0:+\infty)$ in time $t$, $k_{\mathrm{OLTC} 2}(\mathrm{t})$ - the number of switching cycles that the OLTC performed at $t$ time.

Condition 2 is an algorithm that reduces mechanical wear and prolongs the OLTC's lifecycle.

Condition 3: Time limit, state space machine lock.

$$
\operatorname{OLTC.} 3\left(n_{n}, T_{0}\right)=\left\{\begin{array}{c}
T A P 1 \text { UP, if: }: \frac{U_{N}}{n_{n}}<U_{\text {current value }} i T_{0} \geq 1 \\
\text { TAP } n_{0}, \text { if }: U_{N}=U_{\text {current value }} i T_{0} \geq 1 \\
\text { TAP } 1 \text { DOWN, if: } \frac{U_{N}}{n_{n}}>U_{\text {current value }} i T_{0} \geq 1
\end{array}\right\}
$$

where: $T_{0}$ - blocking time of the OLTC $<0:+\infty$ ).

Condition 3 aims to reduce so-called hazard states [1], where due to different reaction times, in certain points of the distribution grid, contradicting or doubling decisions can be made. This condition was proposed due to cooperation with the STATCOM, whose reaction time is measured in milliseconds.

Condition 4: OLTC limitation due to voltage fluctuation caused by the load profile change of quick active power $\mathrm{P}$ or reactive power Q:

$$
\text { OLTC. } 4=\sum_{T_{n}}^{n_{n}} k_{\text {OLTC1 }} \leq k_{n}\left(T_{n}\right)
$$

where: $T_{\mathrm{n}}$ - time in which the number of repetitions of a given position of the tap-changer is measured $n[\mathrm{~s}], k_{\mathrm{n}}\left(\mathrm{T}_{\mathrm{n}}\right)$ - set point of repetitions in time $T_{n}, k_{\text {OLTC1 }}$ - number of OLTC positions (counted separately for each position of tap) according to condition no. 1 
AVC - controller managing the grid voltage, measuring the number of repeating tap changer positions in set time $t$. Due to the protection of mechanical parts of the OLTC and the device's reaction time, the AVC locks the states of repeating fluctuation of the tap changer.

\subsection{Operating conditions of the STATCOM system}

The Static Synchronous Compensator (STATCOM) is a step forward from the device known in the literature as VARCompensator. The STATCOM is based on power electronics, built by using fully controlled IGBT or MOSFET switches. The task of the STACOM compensator is reactive power compensation on a local scale.

To present a mathematical model of the STATCOM, the Clarke and Park transforms were used [11]. These allowed to transform input voltages from a three-phase stationary reference frame into the orthogonal rotating reference frame $d q$.

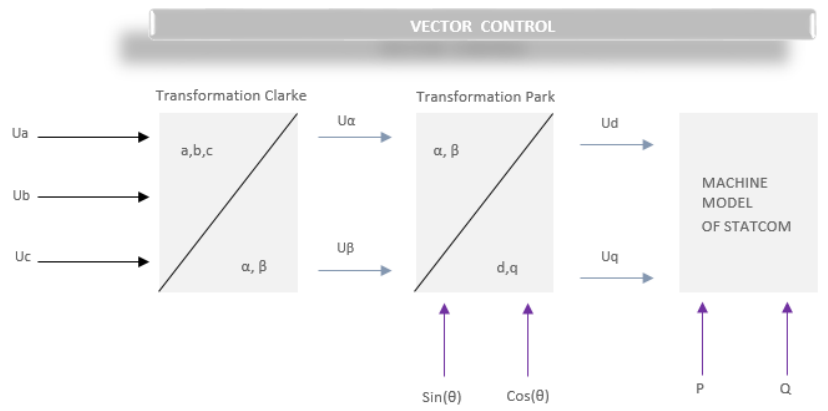

Fig. 7. The Clarke and Park transformation mechanism, where the angle $\theta$ is the angle of synchronization with the power grid
The Clarke and Park mathematical transforms, described with equations (2) and (3), as well as depicted in Figure 7, allow the calculation of an instantaneous voltage positive component in the $d q$ reference frame.

An assumption was made that $U_{\mathrm{a}}, U_{\mathrm{b}}$ and $U_{\mathrm{c}}$ are sampled in the grid, and as a result, discrete waveforms are used in the calculations. These are used in the transformation to the rotating reference frame $d q$. This mechanism is applied in the STATCOM or Energy Storage solutions. In the case of the STATCOM device, additional current vector control is required. It is controlled as follows:

$$
I_{d}^{r e f}=0
$$

The active current component $I_{d}^{\text {ref }}$ in the STATCOM systems is always equal to zero. The passive component is defined as:

$$
I_{q}^{r e f}=k_{p}\left(1+\frac{1}{s T_{i}}\right)\left(Q-\left(\frac{1}{\sqrt{3}}\left(U_{a b} i_{c}+U_{b c} i_{a}+U_{c a} i_{b}\right)\right.\right.
$$

where: $k_{p}$ - the proportional gain factor, $T_{i}$ - integral time.

Using equation (10), voltage control vectors are calculated for the STATCOM output:

$$
V^{\prime} q=V_{q}+\left(i^{r e f}{ }_{q}-i_{q}\right)\left(k_{p}+\frac{k_{p}}{s T_{i}}\right)+i_{d} \omega L
$$

The STATCOM operation can be divided into two stages. In the first stage, the device synchronises with the utility grid, calculating vectors $V_{\mathrm{d}}$ and $V_{\mathrm{q}}[10]$. Next, the converter is started up. Its reference values are calculated on the basis of vectors $V_{\mathrm{d}}$ and $V_{\mathrm{q}}$ and measured $I_{\mathrm{d}}$ and $I_{\mathrm{q}}$ currents. These values are then transformed using the Park transform, and converted into PWM control signals by an SVM modulator. The conversion mechanism is shown in Figure 8.

Using the Clarke and Park transforms described above, and controlling the reactive power value $\mathrm{Q}$, it is possible to achieve the reactive component of the current for a low voltage grid fragment [15].

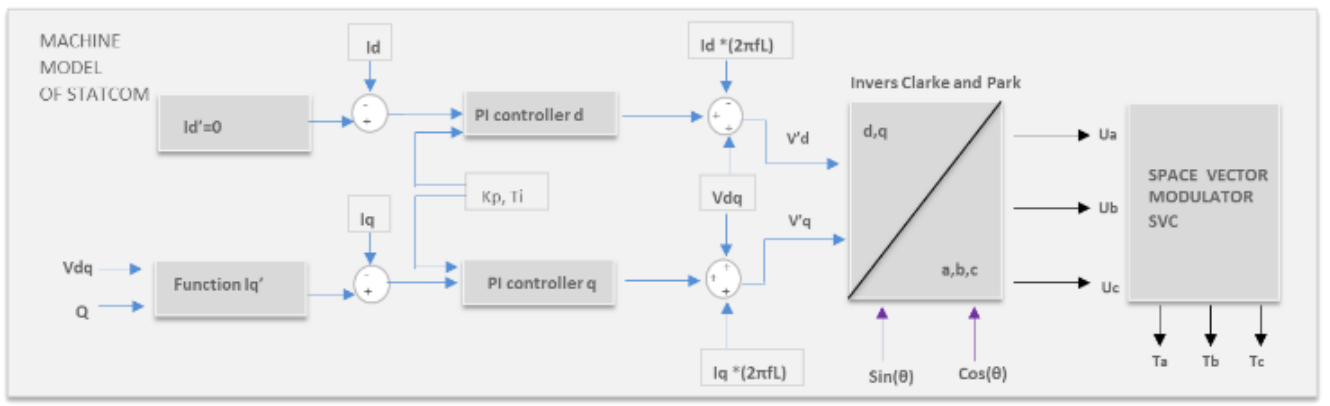

Fig. 8. The STATCOM work mechanism

\section{Schematic diagram of the grid model}

In order to perform the research, a distribution grid fragment (only the low voltage part) presented in Figure 6 was modelled as a simplified circuit. This will allow to define the initial conditions and evaluate the final results.

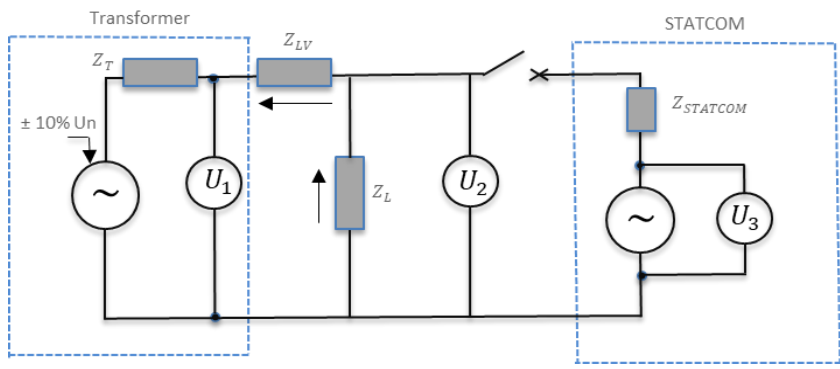

Fig. 9. Schematic diagram of part of the distribution network with the OLTC and STATCOM, where: $U_{I}-$ measurement of the secondary side voltage of the transformer, $U_{2}$-voltage value at the $R L$ load point, $U_{3}-$ voltage value at the STATCOM connection point, $Z_{T}$-transformer impedance, $Z_{L}-$ load impedance, $Z_{L V}-L V$ line impedance, $Z_{S T A T C O M}-$ STATCOM own impedance
Research, based on grid equipment, will be performed for two test cases:

The grid fragment works with a nominal voltage value $-\mathrm{U}_{\mathrm{N}}$, then: $\mathrm{U}_{1}=\mathrm{U}_{\mathrm{N}}$

$\mathrm{U}_{2} \approx \mathrm{U}_{\mathrm{N}}$

$\mathrm{U}_{3}=0$

the grid fragment works out of the nominal voltage range $-U_{\mathrm{N}}$, because $Z_{0}$ has a strong inductive characteristic, then:

$\mathrm{U}_{1}<\mathrm{U}_{\mathrm{N}}$

$\mathrm{U}_{2} \approx \mathrm{U}_{3} \rightarrow \mathrm{f}\left(\mathrm{Q}^{+}\right)$

$\mathrm{U}_{3} \approx \mathrm{U}_{1}$.

Additionally, an important matter is deriving the set value $\mathrm{Q}$ for the grid, which will then be used to calculate the value $V$ 'q. The $\mathrm{Q}$ value is calculated on the basis of on equation:

$$
S(Q)=\frac{\left(U_{1}-U_{2}\right)^{2}}{Z_{T}+Z_{L V}+Z_{L}+Z_{\text {STATCOM }}} \times j \sin \varphi
$$

where: $\varphi$ - the phase of the signal source voltage $U_{1}$ relative to the source $U_{2}$. 


\subsection{Model and test scenarios}

The research carried out was based on the Matlab \& Simulink software, most of it based on Simscape: Power Systems library. These tools allow simulation of electric grid dynamics [13]. A model of the grid fragment is presented in Figure 10.

The basic initial conditions and simulation parameters are presented in Table 2.

Three scenarios were designed during the research, which should be sufficient to provide the answer regarding the strategy choices of voltage control using the OLTC and STATCOM. The starting point for the test are the $V_{\mathrm{d}}$ and $V_{\mathrm{q}}$ (Fig. $4 \& 5$ ) values when there is no additional control. In each scenario, the same load profile was used, as depicted in Figure 1.
Three sets of simulations were carried out, where:

I - active OLTC only;

II - active STATCOM only;

III - active OLTC and active STATCOM.

Table 2. Simulation parameter data

\begin{tabular}{|c|c|}
\hline Simulation parameters & Value \\
\hline Simulation step & $1 \mathrm{e}-5 \mathrm{~s}$ \\
\hline Simulation time & $10 \mathrm{~s}$ \\
\hline Filter STATCOM - L & $0.0012 \mathrm{H}$ \\
\hline Filter STATCOM - C & $0.2 \mathrm{mF}$ \\
\hline $\mathrm{Q}_{\text {STATCOM }}$ & $-10 \mathrm{e} 3 \mathrm{Var}$ \\
\hline $\mathrm{z}_{\mathrm{n}}$ & $2.5 \%$ \\
\hline
\end{tabular}

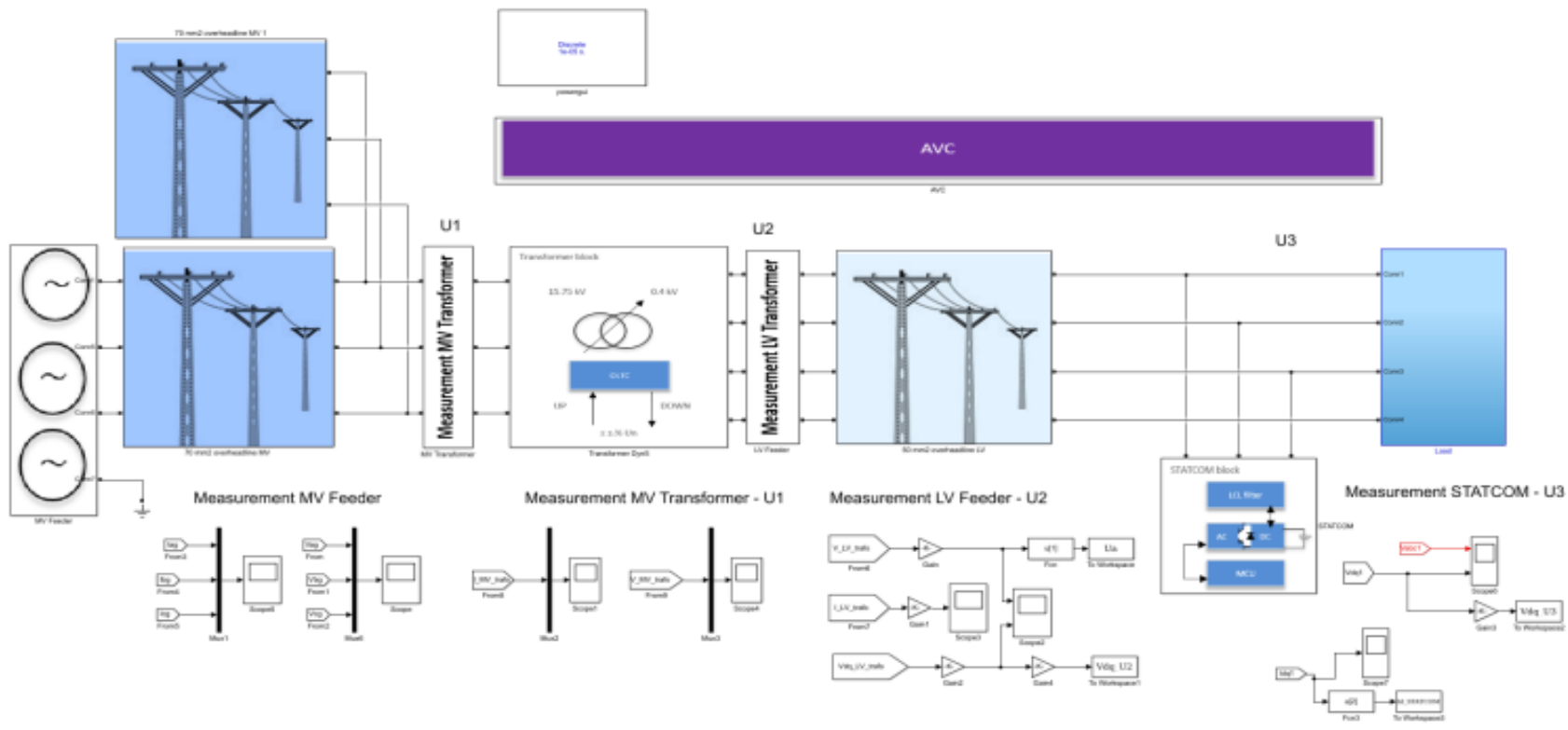

Fig. 10. Model of the OLTC and STATCOM grid in Matlab \& Simulink

\subsection{Test results}

In terms of the $V_{\mathrm{d}}$ and $V_{\mathrm{q}}$ result presentation for each scenario, these values are presented in relation to the rated voltage of $400 \mathrm{~V}$. To present rapid impedance change, and voltage drop on impedance elements, the grid is overloaded on the MV side with active power $\mathrm{P}=20 \mathrm{~kW}$, and on the $\mathrm{LV}$ side according to the graph in Figure 1.

Scenario 1. Simulation results in point V2:

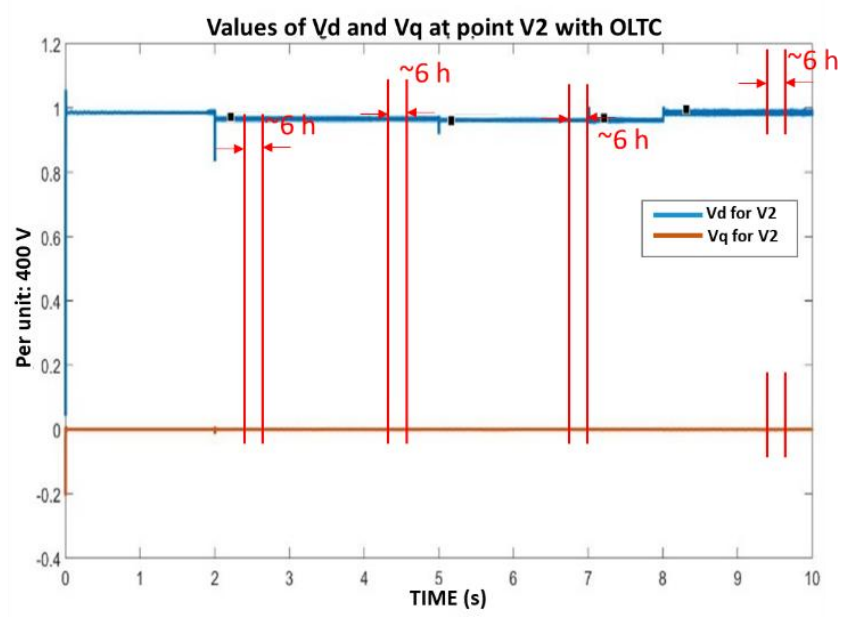

Fig. 11. Values of $V_{d}$ and $V_{q}$ at point $V 2$ with OLTC, scenario 1
The voltage value $V_{\mathrm{d}}$ related to the base value was improved by about $1.5 \%$. $V_{\mathrm{d}}$ is in the admissible range of voltage quality.

Scenario 1. Simulation results in point V3:

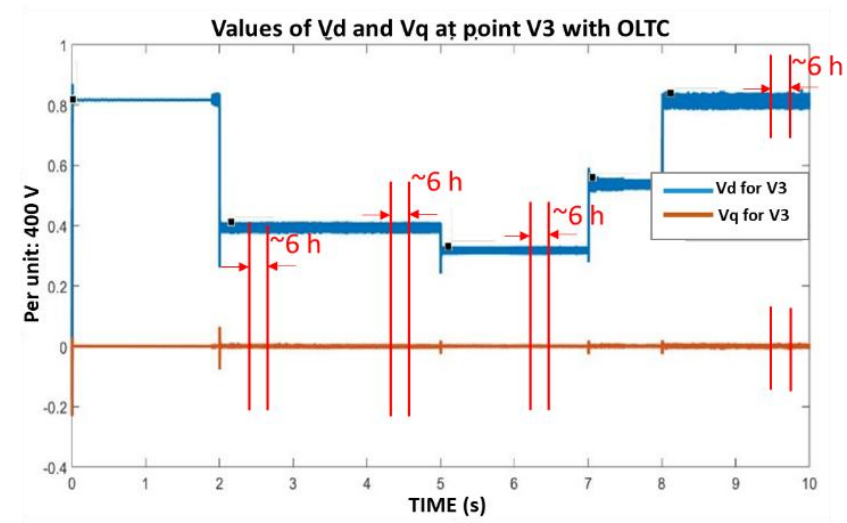

Fig. 12. Values of $V_{d}$ and $V_{q}$ at point V3 with OLTC, scenario 1

The voltage value $V_{\mathrm{d}}$ in relation to the base value was improved by $2.7 \%$. The $V_{\mathrm{d}}$ values are not in the admissible range of voltage quality.

The simulation performed shows that using the OLTC increases the voltage value on the secondary side of the transformer, even in the case of the loading grid on both the MV and LV sides. However, using the OLTC does not improve the voltage value at load point. 
Scenario 2. Simulation results in point V2:

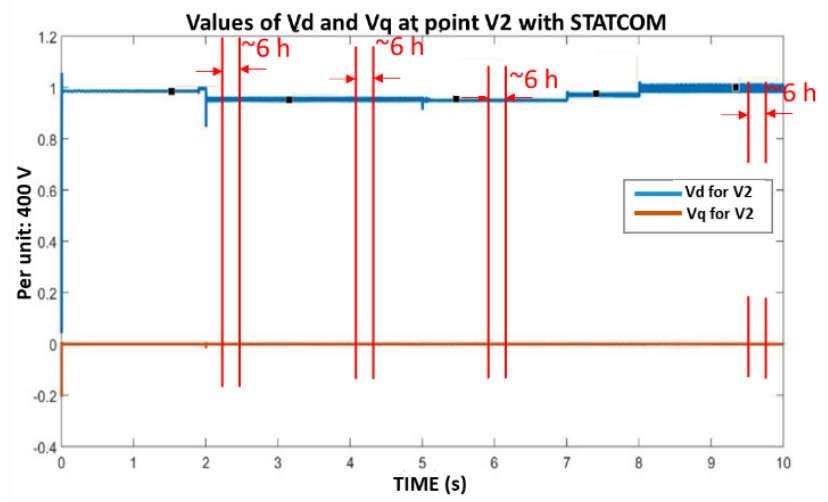

Fig. 13. Values of $V_{d}$ and $V_{q}$ at point V2 with STATCOM, scenario 2

Voltage value $V_{\mathrm{d}}$ related to base value was improved by about $1 \%$. $V_{\mathrm{d}}$ are in admissible range of voltage quality.

Scenario 2. Simulation results in point V3:

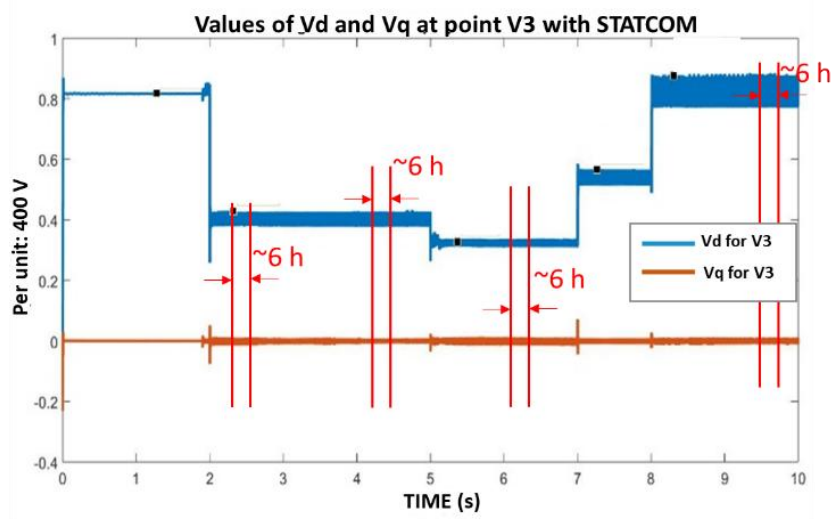

Fig. 14. Values of $V_{d}$ and $V_{q}$ at point V3 with STATCOM, scenario 2

The voltage value $V_{\mathrm{d}}$ in relation to the base value was improved by $7.5 \%$. The $V_{\mathrm{d}}$ values are not in the admissible range of voltage quality. The inductive character of the load was compensated.

The simulation performed shows that using the STATCOM increases voltage values, even in the case of loading the grid on both the MV and LV sides. However, using the STATCOM does not raise the voltage value at load point for RL type loads with the coefficient $\cos \varphi>0.85$.

Scenario 3. Simulation results in point V2:

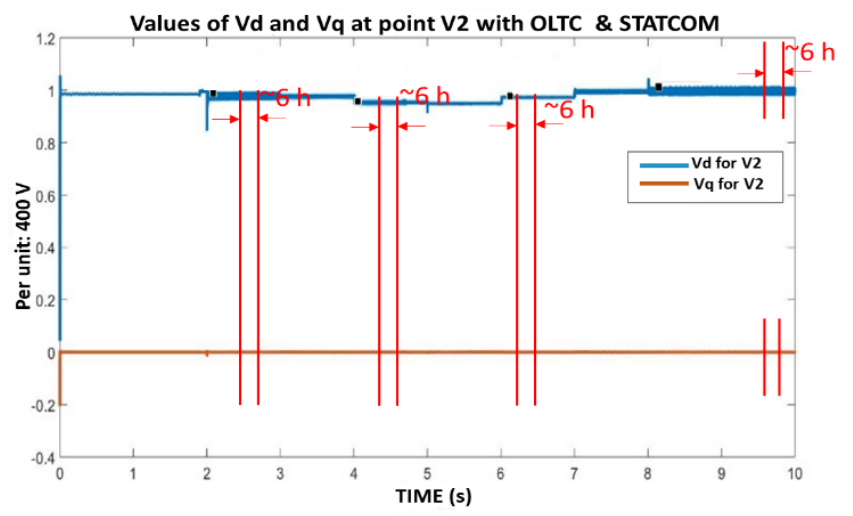

Fig. 15. Values of $V_{d}$ and $V_{q}$ at point V2 with OLTC \& STATCOM, scenario 3
The voltage value $V_{\mathrm{d}}$ in relation to the base value was improved by $2.6 \%$. The $V_{\mathrm{d}}$ values are not in the admissible range of voltage quality.

Scenario 3. Simulation results in point V3:

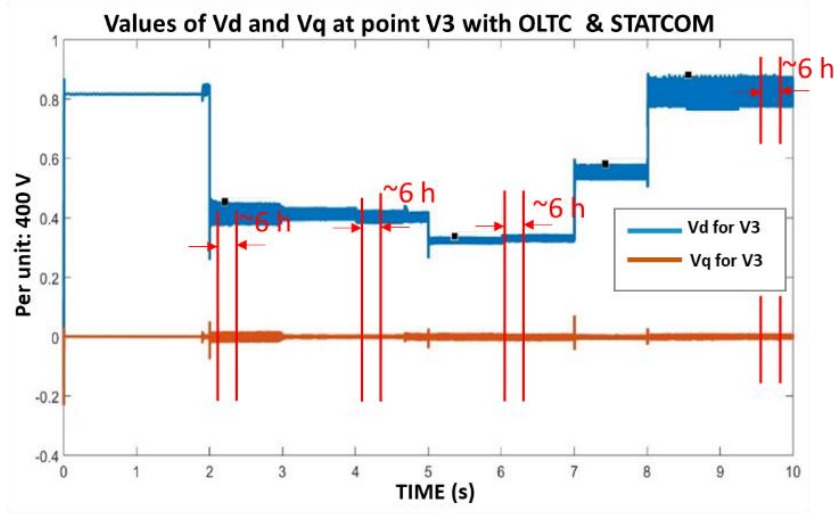

Fig. 16. Values of $V_{d}$ and $V_{q}$ at point V3 with OLTC \& STATCOM, scenario 3

The value of the $V_{\mathrm{d}}$ voltage in relation to the base value improved temporarily by around $12.5 \%$. The inductive character of the line and reception was compensated. The OLTC raised the voltage value on the secondary side. The $V_{\mathrm{d}}$ values are not within the permissible voltage quality range.

\section{Summary}

The choice of the voltage control strategy in the LV grid is dependent on a few initial conditions. First, the active power $P$ and reactive power $Q$ load profile has to have a regulating potential (reactive power reduction). Otherwise, using either the OLTC or STATCOM is unreliable. Next, the depth of the voltage sag and its time needs to be repeatable over a prolonged period and to have a significant impact on the voltage quality. Another thing is that specific conditions need to be established, for example tap switching limitations in a set amount of time $t$ and so on.

Simulation of the OLTC and STATCOM operation on the selected and modelled grid fragment shows limited abilities of active and reactive power transfers using a cable with set crosssection. There should exist an option to control inductive reactive power (resistance systems will not be controlled in the passive part). The management strategy should be based on power electronic devices. It is recommended that those devices are located deep in the grid - close to the isolated fragments, where voltage changes are more significant. Moreover, power electronic devices should first work as voltage regulation devices, and then only with the OLTC. The cases analysed show a need for further research which would include additional devices such as local energy storage. It would then be possible to compensate voltage sags in the LV grid by injecting the active component of current $I_{d}$ at connection point.

\section{Bibliography}

[1] Arif M. A., Ndoye M., Murphy G. V., Kennedy A.: A cooperative game theory algorithm for distributed reactive power reserve optimization and voltage profile improvement. 2017 North American Power Symposium (NAPS), Morgantown 2017, 1-6 [DOI: 10.1109/NAPS.2017.8107250].

[2] Benysek G., Kaźmierkowski M., Popczyk J.: Power electronic systems as a crucial part of Smart Grid infrastructure - a survey. Bulletin of the Polish Academy of Sciences, Technical Sciences 4/2011, 455-473 [DOI:10.2478/v10175-011-0058-2].

[3] Bettanin A., Coppo M., Savio A., Turri R.: Voltage management strategies for low voltage networks supplied through phase-decoupled on-load-tap-changer transformers. 2017 AEIT International Annual Conference, Cagliari, 2017, 1-6 [DOI: 10.23919/AEIT.2017.8240492].

[4] Bobrowska-Rafał M., Krzysztof R., Kaźmierkowski M.: Zapady napięcia kompensacja przy zastosowaniu urządzeń energoelektronicznych typu FACTS. Elektroenergetyka: Współczesność i Rozwój 7/2012, 49-65. 
[5] Borase P. B., Akolkar S. M.: Energy management system for microgrid with power quality improvement. 2017 International conference on Microelectronic Devices, Circuits and Systems (ICMDCS), Vellore, 2017, 1-6 [DOI: 10.1109/ICMDCS.2017.8211710].

[6] Cieślik S.: Analiza symulacyjna strat mocy czynnej w elektroenergetycznej sieci niskiego napięcia $\mathrm{z}$ mikroinstalacjami $\mathrm{z}$ podobciążeniową regulacją napięcia. Poznan University of Technology Academic Journals. Electrical Engineering $82 / 2015,101-111$

[7] Deng J., Zhang G., Geng Y., Wang J.: Design of intelligent on-load tap changer controlled by permanent magnetic actuator. 2017 1st International Conference on Electrical Materials and Power Equipment (ICEMPE), Xi'an, 2017, 270-274 [DOI: 10.1109/ICEMPE. 2017.7982082].

[8] Gao C., Redfern M. A.: A review of voltage control techniques of networks with distributed generations using On-Load Tap Changer transformers 45th International Universities Power Engineering Conference UPEC2010, Cardiff, Wales, 2010, 1-6.

[9] Hanzelka Z.: Zapady napięcia i krótkie przerwy w zasilaniu. Automatyka Elektryka - Zakłócenia 2/2010, 55-70.

[10] Jarzyna W., Zieliński D.: The impact of converter's synchronization during FRT voltage recovery in two-phase short circuits. 2015 Selected Problems of Electrical Engineering and Electronics (WZEE), Kielce, 2015, 1-6.

[11] Kaplon A., Rolek J., Tunia H.: The method for reducing harmonics in input currents of rectifier using a modulation in interphase transformer. 5th IEEE Annual International Energy Conversion Congress and Exhibition (ECCE), Melbourne 2013, 117-121.

[12] Khan I., Verma K.S., Balgopal Faheemullah, Rafi M.: STATic synchronous COMpensator(STATCOM) using FCMLI - A devices for power system security and efficiency Enhancement. 2011 International Conference on Computer, Communication and Electrical Technology (ICCCET), Tamilnadu, 2011, pp. 444-449, [DOI: 10.1109/ICCCET.2011.5762516].

[13] Murali M., Gokhale A., Pandey A.V.; Sharma E.: Modelling, design and comparison of PI and PID controllers for Static Synchronous Compensator (STATCOM). 2016 IEEE 1st International Conference on Power Electronics, Intelligent Control and Energy Systems (ICPEICES), Delhi, 2016, 1-6 [DOI: 10.1109/ICPEICES.2016.7853563]

[14] Rozporządzenie Ministra Gospodarki z dnia 4 maja 2007 r. w sprawie szczegółowych warunków funkcjonowania systemu elektroenergetycznego. Dz. U. Nr 93, poz. 623 z póź. zm.

[15] Zieliński D.: Dynamiczna regulacja moca przekształtników sieciowych, Informatyka, Automatyka, Pomiary w Gospodarce i Ochronie Środowiska IAPGOŚ 1/2016, 59-62.

[16] Zieliński D., Zielińska K.: The impact of a power electronics converter in phase failure work on the power system network. Acta Energetica 3/2016, 155-161.

\section{M.Sc. Eng. Bartlomiej Mroczek}

e-mail: b.mroczek@pollub.pl

In 2002 graduated from the Faculty of Electrical Engineering, Automatics, Computer Science and Electronics* of the AGH University of Science and Technology. From 2018 employed at the Department of Electrical Drives and Machines at the Faculty of Electrical Engineering and Computer Science of the Lublin University of Technology. Studies the dynamics of the changes of energy quality in microgrids by using electric machines and converter systems dedicated to energy storage and reactive power control.

\section{M.Sc. Eng. Karol Fatyga
e-mail: k.fatyga@ pollub.pl}

In 2016 graduated from the Faculty of Electrical Engineering and Computer Science of the Lublin University of Technology. Since then employed as assistant lecturer at the university's Department of Electrical Drives and Machines. His research focuses on power converters, specifically on electric vehicle chargers and converters for coupling the utility grid with energy storage. He is a member of the team working on NCBiR (National Council for Research and Development) projects.

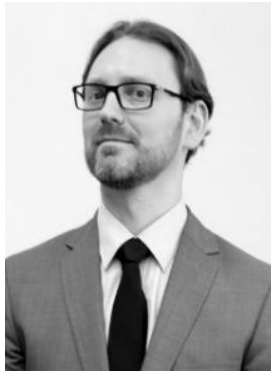

otrzymano/received: 11.04 .2018 przyjęto do druku/accepted: 11.05 .2018 